\title{
My Story of Sal: A Critical Self-reflective Autoethnography Revealing Whiteness in the Classroom
}

\author{
Craig Anthony Wood \\ Griffith University \\ Australia
}

\begin{abstract}
My purpose for conducting the critical self-reflective research described in this article was a desire to improve my effectiveness as a teacher in the field of First Peoples' education. The impetus for undertaking this research was a critical incident in my teaching career that I refer to as My Story of Sal. Writing autoethnographically, I use personal narrative as method, and show My Story of Sal as a representation of curriculum and pedagogy in my teaching praxis. I apply a critical lens of whiteness studies to the narrative to reveal whiteness in my classroom.
\end{abstract}

KEYWORDS: pedagogy, Whiteness, autoethnography, personal narrative, critical reflective practice

\author{
Context of Mystory \\ Whiteness Studies \\ Autoethnography in the Field of Education \\ Research Method \\ My Story of Sal \\ Discussion: Revealing Whiteness \\ The Ethics of Writing My Story of Sal \\ Conclusion \\ Notes \\ References \\ Author Contact
}

I was born on the traditional lands of the Kaurnu People. I grew up playing on the traditional lands and in the waters of the Kaurnu People and the Ngerindjeri People, near the southern coastline of central Australia. I now live and work on the traditional lands of the Jagera People and Turrabal People, about halfway along Australia's eastern coast. I begin this article paying my respect to elders past, present, and emerging of these First Peoples, and I express sorrow at the transgenerational failure of Australian schools to enact a curriculum that is inclusive of First Peoples' narratives, that is culturally appropriate, and that meets the diverse learning needs of First Peoples students. I am non-Indigenous; I am White. For 20 years I have worked in public schools in Queensland, Australia, in various roles including Drama teacher. When I began teaching, I didn't know the names of the Kaurnu, Ngerindjeri, Jagera or Turrabal First Peoples. Their names were omitted from my learning, and their diverse and local knowledges, histories, cultures, and languages continue to be marginalised by the Australian Curriculum. Moreover, aside from my own critical self-reflective research, there are very few professional development opportunities available for me to improve my effectiveness as a teacher in the field of First Peoples' education. 
This autoethnography reports on emerging critical research that seeks to improve my effectiveness as a teacher in the field of First Peoples education by decentring whiteness in my teaching praxis. I present a mystory that I locate in the context of Australia's contemporary education policies related to First Peoples, and I view the mystory through a lens of whiteness studies (Leonardo, 2009; Rodriguez, 2000). I discuss autoethnography in the field of education and personal narrative as research method. I then outline my process of writing My Story of Sal, and I present the mystory (Denzin, 2014; McNiff, 2007). I apply critical self-reflection (Bolton, 2010) to the mystory to generate a thematic analysis (Ellis, Adams \& Bochner, 2011; Ellis, 2004), and I conclude this article with a discussion on ethics pertaining to this autoethnography.

\section{Context of Mystory}

My Story of Sal is an attempt to represent teaching and learning as it might have been experienced by Sal, a First Peoples student in my Drama class. Sal was respected by the school community, well-liked by other students, and had an unblemished student record. Since graduating from secondary school, Sal has gone on to study performing arts at university. However this mystory focuses on a semester of Drama when our class had worked on a play, The Seven Stages of Grieving ${ }^{2}$. The play is devised by two First Peoples artists, Wesley Enoch and Debra Mailman, and it explores issues including racism, identity, violence, and reconciliation. From my dominant position, which includes White and teacher, I thought that the class had been effectively engaged throughout the semester, and I was boldly predicting, to my White teacher colleagues, that at least $80 \%$ of the class were likely to be in "A" and "B" level of achievement bands. However, on the day of the assessment Sal emphatically stated, "I'm not performing." As a consequence Sal was unable to achieve a pass for the semester.

Moving forward from this incident, I performed all of the teacher professional tasks that my school required of me: I emailed Sal's parents, advising them that Sal had refused to participate; I emailed my Head of Department; I logged an entry on Sal's student record that confirmed this was an atypical incident in Sal's schooling. Bothered by this incident, I seek in this mystory to retrace my version of the narrative leading up to the assessment day, unravel complex layers of multiple experiences of curriculum and pedagogy, interrogate my teacher actions, and seek to understand and to educate myself.

I locate My Story of Sal within the context of First Peoples' education in Australia. As a First Peoples student in my class, Sal puts a human face on enrolment data. In 2015 there were 49,323 full-time equivalent First Peoples students enrolled in Queensland public schools, and $40.3 \%$ of these students attended a school in the three south-east urban regions where I teach (Department of Education and Training, 2015). Queensland's First Peoples account for $8.9 \%$ of Queensland's total public school enrolments (Productivity Commission, 2015) and enrolment figures in my own school indicate that approximately $9.0 \%$ of students identify as First Peoples. Supported by this enrolment data, I take the view that developing praxis that addresses inherent racist structures, that destabilises whiteness, and that builds momentum towards reconciliation between Australia's 
First Peoples and non-Indigenous people is both a professional and a moral responsibility.

For over a decade there have been conflicting education policy decisions that have impacted Australian teachers. In 2007, a newly elected federal government began planning for a national curriculum that included embedding Aboriginal and Torres Strait Islander histories and cultures as a cross-curriculum priority (National Curriculum Board, 2009). Following a change of federal government in 2014, a subsequent review of the Australian Curriculum recommended that embedding Aboriginal and Torres Strait Islander histories and cultures should occur "only where educationally relevant" (Australian Government, 2014, p. 247). Furthermore since 2007, the federal government has pursued national targets to Close the Gap on social disadvantage experienced by First Peoples relative to non-Indigenous Australians. In the field of education, Close the Gap targets include halving achievement gaps in reading, writing and numeracy for children by 2018 and halving the gap for First Peoples students in Year 12 (or equivalent) attainment rates by 2020 (Council of Australian Governments, 2013). Recent reporting on education outcomes indicates that Australia is failing to meet these targets (Australian Curriculum Assessment Reporting Authority, 2016); however, access to teacher professional development for programs like the federally funded What Works or Queensland's implementation of Embedding Aboriginal and Torres Strait Islander Perspectives in the Curriculum is limited.

\section{Whiteness Studies}

Whiteness studies problematize Western structures by viewing these structures as Other rather than a practice of normalcy. Giroux (1997) offers that the primary aim of whiteness studies is, "to unveil the rhetorical, political, cultural and social mechanisms through which 'whiteness' is both invented and used to mask its power and privilege" (p. 382). Delgado and Stefanic (2012) add that Whites believe that there is a universally valid truth, an ideal way of knowing and being, and Leonardo (2016) states, "In order for white racial hegemony to saturate everyday life, it has to be secured by a process of domination" (p. 265). Rodriguez (2000) identifies whiteness as a project of "maintaining colourless its colour (and hence its values, belief systems, privileges, histories, experiences, and modes of operation) behind its constant constructions of otherness" (p. 1). hooks (2013), Leonardo (2009), and Smith (1999) state that dominance results from reifying White knowledge, while those whose lived experience is represented by alternative narratives, including First Peoples' knowledges, histories, cultures and languages, are marginalised. Harvey (2007), Leonardo (2009), and Wojecki (2007) note that, as an emerging research methodology, whiteness studies has not yet settled its fault lines; however, proponents are united in their commitment to decentre the White subject. My critical interpretation of whiteness in My Story of Sal decentres my White understanding of the mystory and seeks to understand how Sal might have been experiencing curriculum and pedagogy in my class. 


\section{Autoethnography in the Field of Education}

I approach this teacher research as an autoethnographer. Adams, HolmanJones, and Ellis (2015) posit, "When we do autoethnography, we look inward into our identities, thoughts, feelings and experiences - and outward into our relationships, communities and cultures" (p. 46). Boylorn and Orbe (2014) similarly note that autoethnography encourages the researcher to apply "a critical lens, alongside an introspective and outward one, to make sense of where we are in the context of our cultural communities" (p. 17). Hughes, Pennington, and Makris (2012) state that, in addition to writing about the personal and cultural, autoethnography scholarship should address "existing theory, practice, methodology, and research results" ( $p$. 212), and this view is supported by Adams et al. (2015), Ellis (2004), Ellingson and Ellis (2008), Madison (1999), and Spry (2001). Chang (2008) adds that the process of zooming in and out, between the personal and the cultural, makes autoethnography an ideal tool for reflective professionals, with the caveat that such research ought to demonstrate scholarly understanding of frames from the specific professions. In the field of education studies, Paulo Freire (1998) offers a frame for the critical self-reflective teacher-researcher, stating,

I teach because I search, because I question, and because I submit myself to questioning. I research because I notice things, take cognizance of them. And in so doing, I intervene. And intervening, I educate and educate myself. (Freire, 1998, p. 35).

Freire's (1998) insight into self-questioning frames the relationship between my teaching and my self-reflective research. My research method has included noticing an incident with a student Sal, submitting my teaching praxis to questioning, being cognizant of the beginnings of revelations of whiteness, and intervening to become more effective in educating myself and my students. This interventionist approach to research is supported by Bochner (2000), Denzin (2014), Ellis (2000) and Merriweather (2015), who call for work that empowers storytellers to disrupt dominant narratives, prompts individuals to make sense of experience, and leads to personal transformation. In addition to Freire's (1998) insight, I am also drawn to Elliot Eisner's (1991) notion of the educational connoisseur in Chapter 4 of his book The Enlightened Eye. Eisner (1991) calls for researchers to demonstrate educational connoisseurship that includes four qualities. The first is perceptibility that illuminates the holistic experience in an education setting. Second, Eisner calls for noticeability whereby the researcher is alert to specific features of education. Discernment is the ability to distinguish one educational experience from another, and uniqueness is developing the understanding that educational experiences can rarely be replicated in other settings. I draw on Eisner's four qualities of the educational connoisseur to frame my thematic analysis of My Story of Sal later in this paper

\section{Research Method}

The method that I employ in this research is personal narrative, which Ellingson and Ellis (2008) and Ellis and Bochner (2000) locate within a broad 
umbrella of autoethnographic methods. Leggo (2012) posits that personal narrative is an alternative epistemology to traditional scientific, technological approaches. This concurs with Clandinin and Rosiek (2007), Elbaz-Luwisch (2007), Elliott (2005), McNiff (2007), and Webster and Mertova (2007), who assert that the aim of personal narrative is to discern meaning from moments and reveal layers of understanding from the otherwise tangled messiness of lived experience. Kroth and Cranton (2014) note the relationship between narrative and identity, stating, "There is a core self that is relatively constant over time. Yet, that self or aspects of that self may be challenged by other events and experience" (p.18). Merriweather (2015) agrees, noting the uniqueness of personal narrative as method to acknowledge self, discover self, and change self. Particular to teaching and learning contexts, Clough (2002) and Webster and Mertova (2007) opine that personal narrative as method offers researchers multiple perspectives of stories, shifting teachers by unsettling fixed knowledge and moving them towards holistic, open-ended understandings of phenomena. Kincheloe (2007) posits that critical teaching professionals will embrace open-endedness, appreciate ambiguity in educational practice, and interrogate politically contested spaces. In addition, critical reflection on individual's stories interrogates how stories have been shaped, stored, reshaped, retold, and how these memories contribute to one's personal growth.

My Story of Sal emerges from a two-phase process that begins with recalling a past event, followed by analysis of the event to reveal hidden meanings (Webster \& Mertova, 2007). I draw on Peter Clough's (2002) schematic to offer an insight into my method of recalling the past and combine that with Gillie Bolton's (2010) procedure of "through the mirror writing." Clough's (2002) schematic demonstrates management of data in his own stories of educational research. The schematic includes columns that are titled: Unit of meaning, which identifies a component of the story (e.g., setting or a character); Data source, which cites the origin of the data (e.g., interview transcript, artefacts); and Data method, which is the genre Clough applies to represent experience (e.g., short story, script, poem). Data that contributed to writing My Story of Sal include:

- Two units of meaning: these build the mystory's plot, beginning with Sal's experience of curriculum and lead to the story's climax when Sal refuses to participate in assessment;

- Two types of data sources: these were electronic copies of the subject curriculum, the school's Work Program, unit plan, and teaching resources that I revisited before I began writing, and my memory of events and imagination of representations as I was writing; and

- Data method: this is a poetic representation of voices that might have been present in my classroom.

The second phase of my data collection draws Bolton's (2010) 5-stage technique of "through the mirror writing." The first stage of Bolton's (2010) procedure is the six minute write. Having revisited my data sources, I then engaged in free writing for six minutes without interruption. (Although I needed an additional six minutes.) This writing allowed ideas to emerge, free of constraints of grammar, spelling, punctuation, and story structure. I also wrote free of ethical constraints, resulting in raw data that identify people, places, and events. I discuss ethical considerations in the final section of this paper. The second step of Bolton's (2010) "through the mirror writing" is the story, when the reflective researcher pursues 
threads of stories that emerged in the six minute write and applies what and how choices about storying practice. In My Story of Sal, I wanted to interrogate what Sal and other students might have been experiencing in my class. Having begun to view my practice critically through whiteness studies, I chose to represent My Story of Sal from a position of dominance, and I drafted a poetic representation of my teacher voice. Bolton's third step, read and respond, blurs the boundaries between data interpretation and data analysis, a practice that Chang (2008) notes is not uncommon in autoethnographic research. As a mystory, the story is my interpretation of the semester of Drama classes; however, as I read my dominance, I found a place for a second voice that might be my critical reflexive voice, or some other ethereal voice identifying my whiteness. The second voice might even be Sal reclaiming presence in the story. The final two steps of "through the mirror writing" remain works in progress that will inform my doctoral research, as well as invite dialogue arising from this article. The fourth step is share with a peer, which Bolton (2010) suggests opens the story to new perspectives that can yield deeper understandings of practice. My doctoral research has included blogging five mystories, including a version of $\mathrm{My}$ Story of Sal${ }^{1}$, and inviting feedback from colleagues. The fifth step is developing writing for wider dissemination, such as this article.

\section{My Story of Sal}

The mystory that emerged from my "through the mirror writing" process is a representation of how Sal might have experienced my teaching leading up to the day of the assessment. As Bochner (2007), Denzin (2014), Ellis (2004), Kroth and Cranton (2014), and Richardson (1997) assert, representation of lived experience can only ever be partial, and this mystory is written with an "epistemology of insiderness" (Adams et al., 2015, p. 32). From my "emic" position as teacherresearcher, the text unsettles my dominant teacher knowledge and seeks to consider Sal's alternative experience. The text also includes "etic" positioning, as I begin to observe, listen, and reflect on my teaching in the pursuit of educating myself to understand the impact of my whiteness in my praxis. The "etic" positioning is represented in italicized text as a critical and reflexive voice.

The White teacher says,

"In Drama we will be learning about political activism and social change.

What I'm looking for are techniques that show Brecht's Epic Theatre."

His monologue continues,

"We are learning about overcoming adversity

What I'm looking for is clear communication with your audience."

And then...

"We are learning about Aboriginal and/or Torres Strait Islander peoples."

!!

What I'm looking for is to understand on whose authority do you teach these things? 
With whose cultural knowledge?

With whose permission?

As your teacher,

A man

Who is White

And middle class

And able-bodied

An owner of property;

Trust me,

I know all about these things.

;)

l'm talking

So l'm learning?

I'm teaching

Right. I'm listening.

I have the script

Yes. I know my part.

The Seven Stages of Grieving ${ }^{2}$

So you've selected our class text

I am leading the class discussion

To satisfy the White curriculum

I am asking the questions

We'll all have the same answers.

Now, open your scripts.

Who'd like to read?

Then we'll discuss your knowledge.

"Oi. Hey you! Don't you be waving back at me! Yeah, you with the hat! You can't park here, eh! You're taking up the whole bloody harbour! Just get in your boat and go. Go on, get!

Bloody boat people."

What time and place does this scene refer to?

- questions to elicit information.

Who are the characters?

What's their attitude?

What's their status?

- questions to shape understanding. 
Do we all understand the writer's use of irony?

- questions to press for reflection ${ }^{3}$.

But

When do we do the activism learning?

And when will we overcome adversity?

When will we hear,

Without your edits,

The voices of Aboriginal and Torres Strait Islander peoples?

Now I'm leading the class discussion

On First People's experience??!!

The lesson's buzzing:

I'm on fire

with questions,

and whiteness

My students

are engaged

and replicating

with answers

that please dominance

And all of their answers are right!

says who?

No,

Really,

When did you

ever learn this?

We're collaborating

We're creating,

We're all in,

An inclusive team

I'm prompting participation

I'm nodding

I'm smiling

I'm making eye contact

Drawing in Merry, Lizzie, Darren and Steve. 
Keeping Jennifer, Jake and Tom engaged.

I make eye contact with Sal -

My conscience burns.

My body gasps

and disguises the moment as a blink.

A nano-second has passed

The world restarts.

I look away.

Unsettled

but nodding

and smiling

the lesson goes on.

That feeling...

That moment...

What was that?

Whiteness:

Chinked

not shattered.

This representation of My Story of Sal does not include Sal's decision not to perform a Drama assessment item. Instead, I have tried to represent how Sal might have been experiencing curriculum and pedagogy in my classes in the weeks leading up to the assessment day. The critical self-reflection that Sal's action has prompted reveals a teaching style that appears as monologue rather than dialogue and that replicates dominant narratives rather than critically interrogating such narratives. The discussion that follows considers these revelations through a critical lens of whiteness.

\section{Discussion: Revealing Whiteness}

Autoethnography aims to open dialogue rather than privilege researcher interpretations (Denzin, 2014; Ellis, 2004; Ellis et al., 2011; Webster \& Mertova, 2007). Therefore my intention is not to privilege my findings in the discussion that follows; rather, I attempt to wonder and ask questions. I have framed my discussion with Eisner's four qualities of the educational connoisseur: perceptibility, noticeability, discerning features, and uniqueness.

\section{Perceptibility}


Eisner (1991) posits that perceptibility in educational research refers to illuminating holistic experience. Supported by Bishop (2008), Leonardo (2016), and Smith (1999), in this research I consider the holistic experience to be the systemic privileging of dominant White knowledge that marginalises First Peoples in school curriculum and pedagogy. By submitting myself to questioning, I am unveiling the mechanisms that have influenced my teaching, which I hitherto could have been replicating and which subsequently impacted on Sal. Thus, in My Story of Sal I wonder about conceptions of dominance and otherness in the curriculum. LesterIrabinna Rigney's (2015) keynote address at the Australian Curriculum Studies Association (ACSA) Conference challenged delegates to consider the origins of curriculum in Australia, noting that curriculum did not arrive on a boat from Europe. Dei (2008) similarly states, "We know education did not begin with a colonial encounter" (p.119). Rigney (2015) was challenging neo-colonial dominance that continues to reject understandings of First Peoples as people of learning, and whose 60,000 year heritage embodies curricula that are deeply connected with local lands, seas, waterways, and skies. Rigney's (2015) lament is that First Peoples' knowledges, histories, cultures and languages are not valued by Western schools. This lament is shared by Freire (1993) who observes that Western schools privilege bookish intellectualism over knowledge garnered from lived experiences, and they typically advantage students whose cultural capital "coincides with what the school regards as proper and correct" (p. 17). From my position of dominance, I was satisfied that I was enacting a pedagogy that I thought was dialogical and inclusive, and I was satisfied with my teacher questions and class discussions. However, my critical self-reflection identifies my practice of imposing a hierarchy of knowledge that determined 'proper and correct' White knowledge that oppressed Sal's First Peoples' knowledge.

As a White, male, able-bodied, property-owning teacher in Australia, I am a representation of dominant power, whereas Enoch and Mailman's text includes depictions of First Peoples' characters experiencing discrimination, injustice, oppression, struggle and loss (Sydney Theatre Company, 2008). I now recognise that as a White, monolingual teacher, I am "underprepared to teach children from non-dominant backgrounds" (Brock \& Pennington, 2014, p. 322). Consequently I question the limited capacity of my cultural knowledge in being able to enact a curriculum that appropriately interrogates the issues raised in the play. The aims of the unit were pre-determined by the school's Work Program that I allude to in My Story of Sal; however, Ladson-Billings (2009) observes that it is not what we teach "but it is the way we teach that profoundly affects the way that students perceive the content of that curriculum" (pp.14-15). I now challenge the authority I assumed as the dominant knowledge maker in the class and acknowledge that my whiteness affords me a limited knowledge of lived experience on the themes and issues arising from The Seven Stages of Grieving. I wonder about this missed opportunity to challenge whiteness and enact a critical pedagogy of hope that empowers, rather than marginalises, First Peoples' knowledges (hooks, 2003; Freire, 1994; Giroux, 2011). However I also I note that, despite the generation of theory on whiteness and hope, there are limited examples of practitioner-generated knowledge in this space. Daniels (2010), Nichol (2007), and Tatum (2016) are welcome additions. 


\section{Noticeability}

The quality of noticeability pertains to educational research that is alert to specific features of education. In this section I consider whiteness in education policy as it has impacted my own teaching and learning. My own Bachelor of Education, completed in 1996, included a mere 10 credit points, out of a 320 credit point degree, of First Peoples' perspectives. Earlier I noted limited professional access to programs like What Works! and Embedding Aboriginal and Torres Strait Islander Perspectives in Curriculum. I further note that in my two decades as a public school educator, I have experienced no quality professional development in the area of First Peoples' education. My experience mirrors that of teachers surveyed in Luke et al. (2011), which reports "a lack of sufficient pre- and in-service training preparation in Indigenous education" (p. 230). Ma Rhea, Anderson, and Atkinson (2012) also identified a pattern of limitations in the practices of the Australian teaching workforce pertaining to First Peoples and pointed out that professional development in this field has been "patchy, ad hoc and lacking in cohesiveness" (p. 52). Pennington (2007) similarly observes that American pre-service teacher education programs have yet to mainstream the idea of examining White culture as a factor in teacher education in courses related to content. The result is that teachers and schools replicate White privilege without disrupting it.

Returning to My Story of Sal as a critical reflective teacher-researcher, I acknowledge my failure to challenge dominant thinking as well as my lack of culturally appropriate knowledge. I begin to wonder about the degree to which I was inclusive of multiple perspectives in our conversations about First Peoples, and I wonder about forms of oppression that Sal, and other students, might have been experiencing that my whiteness blinded me to. Most of all, I now wonder to what degree Sal and other students experienced hooks' (2013) notion of domination in my classes. My pedagogy encouraged conversation whereby White students voiced their racialised White narratives of Australia's First Peoples that perhaps reinforced stereotypical perceptions. Sarra (2011) identifies an ontology of "perception" that can be measured through cause and effect, and finds that White perceptions of First Peoples tend to be pejorative and derogatory, resulting in deficit thinking among White educators and negative self-perception amongst First Peoples. I wonder if my class discussions perpetuated pejorative thinking that reinforced White students' negative perceptions of First Peoples, replicating whiteness, and further marginalising Sal. Viewed through this lens, Sal's actions, which systemically appeared to be disengagement from education, may have been a peaceful act of civil disobedience to protest against whiteness. Sal might have been achieving the semester's aims by teaching me about political activism and social change.

\section{Discerning Features}

My discussion on the discerning features of My Story of Sal considers Du Bois' (1903) notion of Double Consciousness that arises from my classroom discussions that marginalised Sal's knowledge. Writing in an American context, Du Bois suggested that Double Consciousness is a process through which African 
American people have an awareness of their own self and culture, but also see themselves through the eyes of political dominance.

It is a peculiar sensation, this double-consciousness, this sense of always looking at one's self through the eyes of others, of measuring one's soul by the tape of a world that looks on in amused contempt and pity. One ever feels his twoness,- -an American, a Negro; two souls, two thoughts, two unreconciled strivings; two warring ideals in one dark body, whose dogged strength alone keeps it from being torn asunder. (Du Bois, 1903, p. xiv)

By positioning dominant and White narratives as proper and correct, those who embody an alternative cultural knowledge are forced to exist in a state of Double Consciousness. Reflecting on My Story of Sal, I wonder how my White, male teaching of The Seven Stages of Grieving affected Sal's Double Consciousness. Sal was drawn from her own First People position to view issues of discrimination, injustice, and oppression through a lens of dominant whiteness that reinforced negative perceptions of First Peoples. From my hierarchical role, I was colonising the text, reframing the First People's experience from my position of dominance, determining correct and proper knowledge, and failing to press students to reflect on counter-narratives that the text offered and that challenge whiteness. By assuming I held privileged knowledge, I was excluding Sal's lived experiences and knowledge as a First People. The choice for Sal was to participate in assessment, which represented repressing her cultural knowledge, or reject whiteness at the price of academic success. Viewed through this critical lens, perhaps Sal's withdrawal of labour was a logical reconciliation of what Du Bois (1903) states are "two warring ideals," and demonstrated her "dogged strength."

\section{Uniqueness}

Eisner (1991) defines uniqueness in educational research as experience that is not replicated elsewhere. I end my thematic analysis by foreshadowing transformational changes in my teaching practice that utilise the unique qualities of the Arts learning disciplines (Anderson, 2015; Gibson, Anderson \& Fleming, 2016) to challenge whiteness and enact critical pedagogy of hope. Freire (1994) posits that an ontology of hope imagines better ways of being, and inspires the struggle to keep us moving forward. Giroux (2011) adds that activism enlivens hope, stating that hope demands "an anchoring in transformative practices" (p. 161), and that progressive educators must pursue a hopeful agenda that "alters dominant relations in power" ( $p$. 161). On the spaces created by pursuing pedagogy of hope, Daniels (2010) suggests that teachers and students find new possibilities of being educators and educated. On the struggle that Freire (1994) identifies, Stewart-Harawira (2005) suggests, "Hope is not a blueprint for the future. What hope brings to us is the belief that different futures are possible" (p. 160).

The rationale of Australian Curriculum: The Arts includes the statement, "The Arts entertain, challenge, provoke responses and enrich our knowledge of self, world cultures and histories," and its aims include developing students' "use of innovative arts practices with available and emerging technologies, to express and represent ideas, while displaying empathy for multiple viewpoints" (ACARA, 2015). Notwithstanding the significant systemic barriers posed to a critical pedagogy of 
hope in The Arts arising from the ad hoc approach to professional development and recent attacks from political conservative forces on the Australian Curriculum, reported by Stinson and Saunders (2016), the Australian Curriculum: The Arts is an ideal site for teachers and students to explore alternative futures and ways of being that are democratic, multivocal, empathic, and that challenge dominant power and knowledge (Bishop, 2008; Dei \& Kempf, 2006; Giroux, 2011; Kincheloe \& Steinberg, 2000; Ladson-Billings, 2009; McLaren, 1997). The Arts are also collaborative and communal (ACARA, 2015), and this opens opportunities to include elders and family members in the classroom (Ainsworth \& McRae, 2006; Bishop, 2008; LadsonBillings, 2009; Sarra, 2011).

As a reflexive caveat, I recognise that the rationale and aims of the Australian Curriculum have not changed. However this critical self-reflection has prompted the beginning of transformation in the way I teach (Ladson-Billings, 2009). As a White antiracist ally, identified by Titone (1998), I acknowledge my limitations: whereas I might aspire to understand my whiteness, challenge the replication of whiteness through curriculum, and support students in their own racial identity (Titone, 1998), the effects of systemic and personal racism are not something that I am likely to experience. I further acknowledge McKinlay's (2012) reflexive article on her own whiteness as a teacher, and her findings related to the vigilance required to remain critical. McKinlay (2012) ominously notes that maintaining critical perspectives is "actually quite easy for someone with...white skin, white identity, white power, and white privilege to forget" (p. 69).

The purpose of this research was to improve my effectiveness as a teacher in the field of First People's education. By adopting Freire's (1998) approach to reflective teacher research, I continue to submit myself to questioning and to educate myself on the impact of my own whiteness as well as systemic whiteness in curriculum and teacher training. Freire (1998) also recognises the importance of intervention arising from reflective teacher research. I am intervening in my praxis by committing to continued questioning and unsettling of whiteness and attempting to shift towards activism that enlivens hope.

\section{The Ethics of Writing My Story of Sal}

As I continue this critical self reflection, I am grateful for the opportunity to consult with First Peoples to maintain cultural appropriateness. Moreover, I am familiar with the guidelines for working in First Peoples' communities that are offered by Martin (2008), Rigney (1997), Smith (1999), and others that are listed on the Griffith University Research Ethics site. My research is informed by data that include representations of First Peoples, so understanding, respecting, and demonstrating cultural protocols are significant considerations of this research. I am committed to a researcher communitarian ethic of no harm throughout this research and its dissemination (Clough, 2002; Denzin, 2014; Webster \& Mertova, 2007).

Denzin (2014) asserts that narrative is always a story about the past, but that it can only ever be a representation of the past. The result of this is that researchers can extend the notion of pseudonyms to de-identifying research contexts, while maintaining the "truth" of the story. Denzin's idea can be seen in practice in Bochner (2000), Clough (2002), and Ellis (2004), which include epilogues disclosing an 
understanding that some of the stories in their narratives might, or might not, have occurred, and that some of the characters might, or might not, be real or at least composites of real people. Nonetheless, the 'truth' in their stories is that something like this happened. This reflexive acknowledgement of the writers does not detract from the shared experiences of "truth" that the work offers the reader. The acknowledgement does not diminish the believability, or plausibility, of the work. Nor does the acknowledgement diminish the goals to evoke emotion in the reader and to lead the reader to wonder about resisting injustice in their own world. I end this section on ethics with a reflexive statement about Sal. I declare that my story of Sal is a truthful story. I did teach a class that included First Peoples. The class did engage in enthusiastic conversations throughout the unit of work, and students did demonstrate commitment to succeed in the assessment. On the day of the assessment task, "Sal" did refuse to participate. That said, "Sal" might, or might not, be the student's name, and the meaning of this story does not rely on gender facts; "Sal" might, or might not, have been female. The class might, or might not, have been Drama, and the assessment might or might not have been a live presentation.

\section{Conclusion}

This critical self-reflection locates My Story of Sal within the methodological field of autoethnography and personal narrative. Viewed through a lens of whiteness studies, my thematic analysis of My Story of Sal, that is a fictional representation of my teaching praxis, has begun to reveal the impacts of whiteness on my teaching. My critical self-reflection suggests a systemic failure in pre-service teacher training and professional development to adequately prepare teachers to meet the educational needs of First Peoples. As teacher research, my reflections have empowered me to determine my professional development needs beyond those of the White systemic education policy makers, and consequently have opened me to the possibilities of pursuing a critical pedagogy of hope in my teaching.

\section{Notes}

1. See thecrystallizingteacher.wordpress.com.

2. Wesley Enoch and Deborah Mailman's (1996) The Seven Stages of Grieving is listed as a suggested text in Queensland's Senior Drama Syllabus.

3. From Morgan and Saxton (1991).

\section{References}

ACARA. (2015). The arts. Retrieved from www.australiancurriculum.edu.au/thearts/introduction 
Adams, T. E., Holman-Jones, S., \& Ellis, C. (2015). Autoethnography: Understanding qualitative research. New York, NY: Oxford University.

Ainsworth, G., \& McCrae, D. (2006). What works. The work program: Improving outcomes for Indigenous students. Successful practice. Abbotsford, VIC: National Curriculum Services.

Anderson, M. (2015). Drama, creativity and learning. International Yearbook for Research in Arts Education 3, 235-240.

Australian Curriculum Assessment Reporting Authority. (2016). NAPLAN achievement in reading, persuasive writing, language conventions and numeracy: National report for 2015. Retrieved from http://www.nap.edu.au/verve/_resources/National_Assessment_Program_Lite racy_and_Numeracy_national_report_for_2015.pdf

Australian Government. (2014). Review of the Australian curriculum: Final report. Retrieved from www.studentfirst.gov.au/strengthening-australian-curriculum

hooks, b. (2003). Teaching community: A pedagogy of hope. New York, NY: Routledge.

hooks, b. (2013). Writing beyond race: Living theory and practice. New York, NY: Routledge.

Bishop, R. (2008). Te Kotahitanga: Kaupapa Maori in mainstream classrooms. In N. K. Denzin, Y. Lincoln, \& L. T. Smith (Eds.). Handbook of critical and Indigenous methodologies (pp. 439-458). Thousand Oaks, CA: Sage Publications.

Bochner, A. (2000). Criteria against ourselves. Qualitative inquiry, 6(2), 266-272.

Bochner, A. (2007). Notes towards an ethics of memory in autoethnographic inquiry. In N. K. Denzin, \& M. D. Giardina (Eds.). Ethical futures in qualitative research (pp. 197-208). Walnut Creek, CA: Left Coast Press.

Bolton, G. (2010). Reflective practice: Writing and professional development. London, UK: Sage Publications.

Boylorn, R. M., \& Orbe, M. P. (Eds.). (2014). Critical autoethnography: Intersecting cultural identities in everyday life. Walnut Creek, CA: Left Coast Press.

Brock, C. H., \& Pennington, J.L. (2014). Exploring three white American teachers' dispositional stances towards learning about racial, cultural, and linguistic diversity. Pedagogies: An International Journal, 9(4), 322-342.

Chang, H. (2008). Autoethnography as method. Walnut Creek, CA: Left Coast Press.

Clandinin, J., \& Rosiek, J. (2007). Mapping a landscape of narrative inquiry. In J. D. Clandinin (Ed.). Handbook of narrative inquiry: Mapping a methodology (pp. 35-75). Thousand Oaks, CA: Sage Publications.

Clough, P. (2002). Narratives and fictions in educational research. Buckingham, UK: Open University Press.

Council of Australian Governments. (2013). Closing the gap in Indigenous disadvantage. Retrieved from www.coag.gov.au/closing_the_gap_in_ indigenous_disadvantage 
Daniels, E. (2010). Fighting, loving, teaching: An exploration of hope, armed love and critical pedagogies in urban teachers' praxis. (Doctoral thesis, University of Rochester, Rochester, USA). Retrieved from http://search.proquest.com. libraryproxy.griffith.edu.au/docview/521953157? accountid=14543

Dei, G. J. S. (2008). Racists beware: Uncovering racial politics in the post modern society. Rotterdam, AQ: Sense Publishers.

Dei, G. J. S., \& Kempf, A. (2006). Looking forward: Pedagogical implications of anticolonialism. In G. J. S. Dei, \& A. Kempf (Eds.). Anti-Colonialism and education: The politics of resistance (pp. 309-314). Rotterdam, AQ: Sense Publishers.

Delgado, R., \& Stefanic, J. (2012). Critical race theory: An introduction. New York, NY: New York University Press.

Denzin, N. K. (2014). Interpretive autoethnography (2 ${ }^{\text {nd }}$ ed.). Thousand Oaks, CA: Sage Publications.

Department of Education and Training. (2015). Indigenous student enrolments by region. Retrieved from www.education.qld.gov.au/schools/statistics/pdf/ indigenous-student-enrolments-by-region-august.pdf

Du Bois, W. E. B. (1903/1994). The souls of Black folk. New York, NY: Dover Publications.

Eisner, E. (1991). The enlightened eye: Qualitative inquiry and the enhancement of educational practice. New York, NY: MacMillan Publishing.

Elbaz-Luwisch, F. (2007). Studying teacher's lives and experience: Narrative inquiry into K-12 teaching. In J. D. Clandinin (Ed.). Handbook of narrative inquiry: Mapping a methodology (pp. 357-382). Thousand Oaks, CA: Sage Publications.

Ellingson, L., \& Ellis, C. (2008), Autoethnography as constructionist project. In J. A. Holstein, \& J. F. Gubrium (Eds.). Handbook of constructionist research (pp. 445-465). New York, NY: The Guilford Press.

Elliott, J. (2005). Using narrative in social research: Qualitative and quantitative approaches. London, UK: Sage Publications.

Ellis, C. (2000). Creating criteria: An ethnographic short story. Qualitative inquiry, $6(2), 273-277$.

Ellis, C. (2004). The ethnographic I: A methodological novel about autoethnography. Walnut Creek, CA: AltaMira Press.

Ellis, C., Adams, T. E., \& Bochner, A. P. (2011). Autoethnography: An overview. Forum: qualitative social research, 12(1), 273-290.

Ellis, C., \& Bochner, A. (2000). Autoethnography, personal narrative, reflexivity: Researcher as subject. In N. K. Denzin, Y. S. Lincoln (Eds.). Handbook of qualitative research ( $\left.2^{\text {nd }} E d.\right)$ (pp. 736-768). Thousand Oaks, CA: Sage Publications.

Enoch, W., \& Mailman, D. (1996). The seven stages of grieving. Brisbane, AU: Playlab.

Freire, P. (1993). Pedagogy of the city. New York, NY: Continuum. 
Freire, P. (1994). Pedagogy of hope: Reliving pedagogy of the oppressed. New York, NY: Continuum.

Freire, P. (1998). Pedagogy of freedom: Ethics, democracy, and civic courage. Lanham, MD: Rowman and Littlefield.

Gibson, R., Anderson, M., \& Fleming, J. (2016). The qualitative findings: Quality arts pedagogy. In J. Fleming, R. Gibson, \& M. Anderson (Eds.). How arts education makes a difference: Research examining successful classroom practice and pedagogy (pp. 106-120). Abingdon, UK: Routledge.

Giroux, G. A. (1997). White squall: Resistance and pedagogy of whiteness. Cultural Studies, 11(3), 376-389.

Giroux, H. A. (2011). On critical pedagogy. New York, NY: Bloomsbury.

Harvey, J. (2007). Whiteness and morality: Pursuing racial justice through reparations and sovereignty. Gordonsville, VA: Palgrave Macmillan.

Hughes, S., Pennington, J. L., \& Makris, S. (2012). Translating autoethnography across the AERA standards: Toward understanding autoethnographic scholarship as empirical research. Educational Researcher, 41(6), 209-219.

Kincheloe, J. L. (2007). Critical pedagogy in the twenty-first century: Evaluation for survival. In P. McLaren, \& J. L. Kincheloe (Eds.). Critical pedagogy: Where are we now? (pp. 9-42). New York, NY: Peter Lang Publishing.

Kincheloe, J. L., \& Steinberg, S.R. (2000). Constructing a pedagogy of whiteness for angry white students. In N. M. Rodriguez, \& L. E. Villaverde (Eds.). Dismantling White privilege: Pedagogy, politics and privilege (pp. 178-197). New York, NY: Peter Lang Publishing.

Kroth, M., \& Cranton, P. (2014). Stories of transformative learning. Rotterdam, AQ: Sense Publishers.

Ladson-Billings, G. (2009). The Dreamkeepers: Successful teachers of African American children ( $2^{\text {nd }}$ ed.). San Francisco, CA: Jossey-Bass.

Leggo, C. (2012). Sailing in a concrete boat: A teacher's journey. Rotterdam, AQ: Sense Publishers.

Leonardo, Z. (2009). Race, whiteness, and education. New York, NY: Routledge.

Leonardo, Z. (2016). The colour of white supremacy: Beyond the discourse of 'White Privilege'. In E. Taylor, D Gillborn, \& G. Ladson-Billings (Eds.). Foundations of Critical Race Theory in education ( $2^{\text {nd }}$ ed.) (pp. 265-277). New York, NY: Routledge.

Luke, A., et al. (2011). A formative evaluation of the Stronger Smarter Learning Communities Project: 2011 Report. Brisbane and Canberra: Queensland University of Technology and Department of Education, Employment and Workplace Relations.

Ma Rhea, Z., Anderson, P. J., \& Atkinson, B. (2012). Improving teaching in Aboriginal and Torres Strait Islander education: National Professional Standards for Teachers Standards Focus Areas 1.4 and 2.4. Retrieved from arrow.monash.edu/vital/access/manager/Repository/monash:118407

Madison, D. S. (1999). Performing theory/embodied writing. Text and Performance 
Quarterly, 19, 107-124.

Martin, K. L. (2008). Please knock before you enter: Aboriginal regulation of outsiders and the implications for researchers. Teneriffe, AU: Post Pressed.

McKinlay, E. (2012). PEARL: A Reflective story about decolonising pedagogy in Indigenous Australian studies. Australian Journal of Indigenous Education, 41, 67-74.

McLaren, P. (1997). Developing a pedagogy of whiteness in the context of postcolonial hybridity: White identities in global context. In N. M. Rodriguez, \& L. E. Villaverde (Eds.). Dismantling White privilege: Pedagogy, politics and privilege (pp.150-157). New York, NY: Peter Lang Publishing.

McNiff, J. (2007). My story is my living educational theory. In D. J. Clandinin (Ed.). Handbook of narrative inquiry: Mapping a methodology (pp.308-329). Thousand Oaks, CA: Sage Publications.

Merriweather, L. R. (2015). Autoethnography as counter-narrative: Confronting myths in the academy--an African American female perspective. In S. D. Hancock, A. Allen, \& C. W. Lewis (Eds.). Autoethnography as lighthouse: Illuminating race, research and the politics of schooling (pp.47-66). Charlotte, NC: Information Age Publishing.

Morgan, N., \& Saxton, J. (1991). Teaching, questioning, and learning. New York, NY: Routledge.

National Curriculum Board. (2009). Shape of the Australian Curriculum: History. Retrieved from http://www.ncb.org.au/verve/_resources/The_Shape_of_the_ National_Curriculum_paper.pdf

Nichol, F. (2007). Are you calling me racist? Teaching critical whiteness theory in Indigenous sovereignty. In D. W. Riggs (Ed.). Taking up the challenge: Critical race and whiteness studies in a postcolonial nation (pp. 17-33). Belair, AU: Crawford House Publishing.

Pennington, J. L. (2007). Silence in the classroom/whispers in the halls: Autoethnography as pedagogy in white pre-service teacher education, Race Ethnicity and Education, 10(1), 93-113.

Productivity Commission. (2014). Report on government services. Retrieved from www.pc.gov.au/research/ongoing/report-on-government-services/2015/ childcare-education-and-training/school-education

Richardson, L. (1997). Fields of play: Constructing an academic life. New Brunswick, $\mathrm{NJ}$ : Rutgers University Press.

Rigney, L. I. (1997). Internationalisation of an Indigenous anti-colonial cultural critique of research methodologies: A guide to Indigenist research methodology and its principles. Journal for Native American Studies, 14(2), 109-121.

Rigney, L. I. (2015). Garth Boomer Memorial Lecture. Australian Curriculum Studies Association, Adelaide Convention Centre, Adelaide, Australia.

Rodriguez, N. M. (2000). Projects of whiteness in a critical pedagogy. In N. M. Rodriguez, \& L. E. Villaverde (Eds.). Dismantling White privilege, pedagogy, politics and whiteness (pp. 1-24). New York, NY: Peter Lang Publishing. 
Sarra, C. (2011). Strong and Smart -- Towards a pedagogy for emancipation: Education for first peoples. London, UK: Abingdon.

Smith, L. T. (1999). Decolonising methodologies: Research and Indigenous peoples. London, UK: Zeal Books.

Spry, T. (2001). Performing autoethnography: An embodied methodological praxis. Qualitative Inquiry, 7(6), 706-732.

Stewart-Harawira, M. (2005). Cultural studies, Indigenous knowledge and pedagogies of hope. Policy Futures in Education, 3(2), 153-163.

Stinson, M., \& Saunders, J.N. (2016). Drama in the Australian National Curriculum: Decisions, tensions and uncertainties. Research in Drama Education: The Journal of Applied Theatre and Performance 21(1), 93-104.

Sydney Theatre Company. (2008). The seven stages of grieving: Teacher's resource kit. Retrieved from http://d2wasljt46n4no.cloudfront.net/files/Community/ Resources/past\%20production\%20resources/7\%Stages\%20Teachers\%20Not es.pdf

Tatum, B. D. (2016). Teaching White students about racism: The search for White allies and the hope of restoration. In E. Taylor, D. Gillborn, \& G. LadsonBillings (Eds.). Foundations of critical race theory in education (pp.278-288). New York, NY: Routledge.

Titane, C. (1998). Educating the White teacher as ally. In J. L. Kincheloe, S. R. Steinberg, N. M. Rodriguez, \& R. E. Chennault (Eds.). White reign: Deploying whiteness in America (pp. 159-176). New York, NY: St. Martin's Press.

Webster, L., \& Mertova, P. (2007). Using narrative inquiry as a research method: An introduction to using critical event narrative analysis in research on learning and teaching. Abingdon, UK: Routledge.

Wojecki, A. (2007). Learning 'race': Personal narrative as pedagogy in critical whiteness studies - pitfalls or potential? In D.W. Riggs (Ed.). Taking up the challenge: Critical race and whiteness studies in a postcolonising nation (pp. 51-70). Adelaide, AU: Crawford House Publishing.

\section{Author Contact}

Craig Anthony Wood: craig.wood@griffithuni.edu.au

Griffith University, 170 Kessels Rd, Nathan QLD 4111, Australia 